\title{
Prevention of STI and teenage pregnancies through sex education
}

\begin{abstract}
Different names are used when referring to sex education, as well as there are different ways to teach the subject. Yet, it remains an essential part of the school curriculum. Using different curricula may yield various results. The content of sex education classes is dependent on various cultural and social aspects, specific to the certain country. In Poland, sex education-related topics are brought up during classes of Introduction to Family Planning, as it is called in Polish. The Ministry of Education is responsible for shaping sex education policies. The curriculum mostly focuses on STI-related diseases (including HIV/AIDS), contraceptive methods and teen pregnancy issues. Unfortunately, psychological aspects of sex or sexual assault subjects are rarely discussed upon. As a result, sexual initiation often results in unwanted pregnancies or infections. Shame is a huge obstacle to effective communication on these topics between teens ant their parents. This shows the need for organizing educational meetings for parents or carers to help them start a conversation on this delicate subject with their kids. Sex education should be focused on presenting upright knowledge with medical accuracy, which will be an addition to the content provided by parents. Well-prepared teachers can have impact over lowering the rate of sexually transmitted infections and teenage pregnancies. Sex education has also a significant influence over promoting responsible sex and increasing teens' awareness.
\end{abstract}

Keywords: sex education, sexually transmitted infections, STI, adolescent, pregnancy, prophylaxis/prevention.

DOI: $10.1515 /$ pjph-2016-0010

\section{INTRODUCTION}

Sex education remains a controversial subject in public discussion. These classes are expected to center on issues like sexual and reproductive health, responsible sex behavior, preventing sexually transmitted diseases and sexual assault. According to international standards of sex education, it should be taught in schools of all levels. Sex education centers on physical, biological, social and emotional aspects of sexual health, not only on knowledge related to STI or pregnancy prevention [1]. Access to sex education is considered one of human rights [2]. Adolescence is a time when children become youth and start discovering the physiology of their bodies and create own sexual behavior related to way of understanding own intimacy and ability to self-control. Lack of proper sex education programs can result in increased rates of teen pregnancies and spread of STIs. The term teenage mother is used to refer to girls who become pregnant or give birth before reaching the age of $18[3,4]$. The list of sexually transmitted infections includes syphilis, gonorrhea, chlamydia, trichomoniasis, herpes, hepatitis B and C, HIV/AIDS and HPV. Some of them are curable and some only treatable. There are many differences between symptoms, treatment and risk of infection, which is why a well-prepared teacher should become the ultimate source of information on sex for teens, rather than the Internet or their peers. Teen pregnancy and STIs can burden people for the rest of their lives [5]. Young people look for knowledge in many sources. Parents who have the biggest impact over shaping young people's behavior, should become authorities in the field of sex education as well. Specialists would never even have a similar impact as the parents do. Teaching about hormonal physiology, the menstrual cycle in particular, determining fertility days and talking about natural and artificial contraception methods and birth control methods, is uniformly essential [6]. Sex education is a life-long process. Even though parents should be the first to teach sexual health to their children, most of them do not feel confident to talk with their own children about sex, which is why school should support them in that area. Trained educators can provide learning in neutral environments, which will encourage the youth to have an open discussion and asking questions [7]. The lack of proper sex education can have negative impact on psychological development of the adolescent. In a digital age, where young people have almost unlimited access to the Internet or other media, where they are exposed to various poor role models, false images of sexual life or erroneous standards of beauty, sexual needs of adolescents can raise fears and be a cause of distress. Not having sufficient knowledge can lead to problems with accepting one's

\footnotetext{
${ }^{1}$ Students' Circle of Medical Simulation, Department of Didactics and Medical Simulation, Medical University of Lublin, Poland

${ }^{2}$ Students' Circle at the Human Anatomy Department, Medical University of Lublin, Poland

${ }^{3}$ Students' Circle at the Department of Obstetrics and Pathology of Pregnancy, Medical University of Lublin, Poland

${ }^{4}$ Human Anatomy Department, Medical University of Lublin, Poland
} 
own body, low self-esteem and lack of self-confidence $[1,6,8]$. As young people lack knowledge on this matter, most governments implement special sex education programs in schools. Overall they can be divided into abstinence-only and comprehensive programs. The former program mostly centers on encouraging the youth to abstain from any form of sexual activity. The goal is to convince young people that abstinence is the only certain way to avoid unintended pregnancies and sexually transmitted infections $[9,10]$. Comprehensive sex education classes let students gain new knowledge in the field of sex in an age-appropriate way. The curriculum involves both knowledge about sexual health and human relationships. The idea is to teach students that abstinence is an option they can always choose and also to promote contraception or safe sex practices [11-13]. There are also programs of holistic sex education, which means combining the two mentioned-above programs and putting them in a wider perspective, paying attention to personal and sexual development. Holistic view on sexuality covers both biological and psychological aspects of sex $[6,14]$. Sex education curricula differ by country. In some cases, they involve games, watching movies, theater and even using the Internet in class, instead of lectures or peer education. In most European countries it is school teachers who are responsible for sex education lessons. Doctors and school nurses are rarely involved in this field. It seems to be a positive trend, since otherwise the class may turn into biology-like classes - with too much medical knowledge involved. Yet, healthcare professionals might prove a good choice for the youth to turn to and talk sex-related topics with, including physical or sexual abuse, pregnancy or STI. Although visiting healthcare promises is rare, it proves a rather effective method. Another way of preparing sex education lessons is to involve voluntary and non-governmental organizations, which can help by performing seminars and providing counseling services [1]. This article is written as an effect of many years' experience of working with teenagers during peer education lessons.

\section{Sex education in Europe}

Despite the numerous differences that exist between European countries, there are some similarities. Each country tries to overcome obstacles and has different experiences providing sex education to citizens. Some curricula address biological and health issues more than the relationship aspect, while others center on STI prevention. There are also various ways of including sex education in the school's timetable. In some cases, sex education classes are integrated into other classes, widening their scope to include some additional material related to human sexuality, interpersonal skills or human sexual anatomy. In other countries, like Portugal sex education is taught as a separate subject by teachers of biology, religious education, geography or philosophy [1]. Sex education classes were first introduced in Scandinavia. Initially, they were optional (1942), then, they became mandatory for all students (1955), which had significant impact on reducing the rates of HIV and lowering the number of unwanted pregnancies [2]. During the last decade of $20^{\text {th }}$ century, classes on how to prevent unwanted pregnancies started to appear in many European countries [6]. The lowest rate of adolescent pregnancies $(4 / 1000)$ is reported in the Netherlands, also reduced the number of performed abortions and considered as a result of using contraception by sexually active adolescents [2].

\section{Sex education in Poland}

Since 1966, sex education classes have been taught in every region of Poland, yet throughout the years they have been based on different curricula. These changes were mainly linked with political changes. In 1973, the Communist Party of Poland created a subject named Preparation for the Life in the Socialist Family [1]. Some changes in sex education happened in 1989, right after the collapse of Communism, but still the Catholic Church has huge impact on sex education development. According to IPPF since 1990, "sex education textbooks use non-scientific language and reflect a philosophical rather than a biological notion of sexuality. Sex education tends to focus on traditional values and family role" [1]. At the moment, it is the Ministry and Department of Education that oversees sex education in Poland. In 2001, the Ministry of Education published a program of Education for Family Life classes $[1,15]$. Sex education in Poland is taught at schools in form of an independent subject called "education for family life" and it is aimed at students older than 12. Classes involve lectures and workshops, as well as meeting with external teachers or peer education. Usually, it is teachers of other subjects or nurses, as well as specially-trained sex educators who conduct these classes. Even though the "education for family life" is taught at every school, parents must sign an agreement allowing children to attend these classes. Since sex education classes are believed (often by both parents and children) to be either boring or useless, many children abstain from them. One of the biggest problems in sex education is that sexuality is still considered a taboo subject in Poland. Unfortunately, hardly anyone sees the importance of sex education for young people [1]. In 2015, Education Research Institute conducted a study about opinions and expectations of teenagers and their parents on subject of sex education. When asked about the main sources of knowledge concerning sexual health, young people pointed at peers (the first place), then family (more often the mother than the father), sex education teachers, then girlfriend or boyfriend, the internet and magazines. Parents were also inquired about this and they claimed that their children acquire knowledge from parents, sex education teachers or peers. Almost one third of parents declared that they would attend classes on selected sexuality-related topics, in order to better prepare themselves for talking to children about it. Over a half of the respondents claimed that sex education classes should be taught by a specialist outside the school. In the perfect world, it would have been a doctor, psychologist or sex educator. A significant number of students could not provide a correct answer to the questions concerning basic knowledge of human anatomy and functions of the reproductive system, STI, recognizing fertile days and birth control methods [16]. In the survey, conducted in 2004-2007 among students in Łódź, an evaluation of sex education in Poland was performed. Up to $60 \%$ students did not know in which day of menstrual cycle the chances to get pregnant were the highest [17]. That indicates that teaching sex education still need to be improved. Ponton, a group of sexual educators, published a report on sex education classes in Poland. The report contained data collected via e-mail from over 600 students from all around Poland. The students could anonymously tell about their experiences and expectations of sex education classes. Among most frequently brought subjects during sex education classes were topics such as human sexual anatomy, maturation, hygiene, reproductive rights, safe sex, contraception focusing mostly 
on Fertility Awareness-Based Methods, information related to pregnancy, sexually transmitted infections, relationships and family topics. Assertiveness and sexual assault are rarely discussed upon. Sex education classes have received both positive and negative feedback from the students. Most people would say that teenagers are interested only in contraceptive methods and STI. What do students want to talk about during sex education classes? The answers were surprising. A report published by Ponton group shows that young people want to talk about many things related to sex, relationships and homosexuality. High school students paid much more attention to less formal ways of teaching. Still, educators should keep in mind that the discussed topics should be age-appropriate [18].

\section{Sex education and disease prevention}

Even though numerous initiatives are promoted, the rate of unintended pregnancies and sexually transmitted infections is still, not only in the US, but in other countries as well. This is the reason why different sex education programs are popularized in many countries According to a research study conducted by Department of Health and Human Services, it appears that during the last 5 years the youth started to use more hormonal contraception and condoms. Thus, the rate of teenage pregnancies decreased. Although the studies show that most unintended pregnancies are among women aged 15-19, moreover statistically 1 in 3 pregnancies lead to an abortion. The terrifying fact is, that among sexually active adolescents, almost 1 in 4 has or had STI. Furthermore, only $57 \%$ of the respondents, who admitted they had been sexually active within past 3 months, claimed they had used barrier contraception during their last intercourse [19]. In a review study published by Kirby et al. in 2006, some 83 sex education curricula were compared (56 were conducted in the United States; 9 in other developed countries (Canada, Netherlands, Norway, Spain, and the United Kingdom); and the remaining 18 in developing countries (Belize, Brazil, Chile, Jamaica, Kenya, Mexico, Namibia, Nigeria, South Africa, Tanzania, Thailand, and Zambia). Sex and HIV education programs were compared on sexual behavior and mediating factors among youth under 25 years old anywhere in the world. The study looked at the following aspects: frequency of intercourse, number of sexual partners, increased condom use, contraceptive use, sexual risk taking, STI impact, pregnancy rate. Some of the programs focused on aspects related to public health, while two thirds of them centered also on positive impact that these programs have over sexual behavior.

Many of the programs that were looked upon either decreased sexual activity among young people or had positive influence over using contraceptive methods. Meaningful effect was noticed on psychological influence to sexual behavior. There is evidence that programs like that did not have any negative effects nor increased sexual activity. Almost all educators had received proper training before curriculum activities started. In order to involve the youth more and make it easier to understand the information, classes included many interactive elements such as role playing, simulations or worksheets [20]. Comprehensive sex education has many advantages. It helps young people make informed decisions and build healthy relationships, it shows the value of abstinence and prepares young people for starting to be sexually active. That kind of education informs the youth about the health benefits and side effects of all contraceptives, as a way to prevent unwanted pregnancy and reduce the risk of STI. Also, it encourages families to talk about sexuality, teaches young people how to make conscious decisions about their sexuality [21]. Although abstinence-only programs have a positive impact over delaying the age at first sexual intercourse, comprehensive programs have the same impact and additionally increase use of contraceptives [20]. Overall, it appears that studies, have far more likely positive influence on sexual behavior than negative one.

In 2007, Santelli J. described the aspect of medical accuracy in sex education. According to his study medical accuracy may be useful when preparing health education standards. If sexually active adolescents received proper information, they would be prepared to make informed choices. The studies show that patients expect to be informed about sexually transmitted infections, prevention and treatment options, considering it as one of basic human rights. It is believed that access to information about condoms and other forms of contraception should be granted to all students who are sexually active or will be in the close future [22]. Adolescents need information and developed life skills, such as critical thinking, decision making, assertiveness, ability to ask questions and seek help and negotiation skills to make conscious choices. It is the society's responsibility grant access to provide teens with access to sexual and reproductive healthcare. Sex education may have a positive impact on attitudes toward reproductive and sexual health of young people [1]. Various studies show that providing accurate information about contraception methods reduced risky behaviors of young people, as well as decreased the number of unintended pregnancies and STI [23]. Abstinence-only programs hardly as effective as comprehensive sex education combined with access to contraception [12]. Adolescents of various educational background - those who attended abstinence-only classes and comprehensive classes were compared against those who had not received any formal sex education. The results showed that those adolescents who received formal sex education had much lower risk of unintended pregnancy and risky sexual behavior than young people who did not have opportunity to receive sex education at all. Another significant conclusion was that teaching about birth control methods was not associated with growth of sexual activity. Moreover, the risk of pregnancy was much lower in those adolescents who had received comprehensive education than those who received abstinence-only or no sex education at all [12]. Sweden is a great example of a country in which sex education programs work effectively. Sex education policies were changed in 1975, afterwards teenage birth rate fall by 80 per cent within two decades. In Sweden number of STI declined by $40 \%$ in 1990s while sexually transmitted infections were on the rise in the UK and USA [24]. Conversely, there are some examples that abstinence-only education is not as effective as it is considered to be. As an example in Texas even was $\$ 10 \mathrm{~m}$ was spent on program, which promoted abstinence from any sexual activity, the effect was close to zero. Despite these efforts, Texas ranked $4^{\text {th }}$ in terms of the number of HIV infections. Plus to that, the number of teenage pregnancies remained high - the slowest decline in the number of birth among 15 to 17 years olds [24]. WHO studies implicate that introduction of sex education programs in schools often delay sexual initiation and decrease sexual activity among adolescents. Well-prepared sex education will certainly help young people in adolescence and prepare them to make conscious decisions [6]. The studies presented above suggest that many sex education programs have 
shown decrease of risky sexual behaviors or have an influence on higher contraceptive use. These research also implicate that introducing sex education into schools decreased STI rate and number of adolescent pregnancies. Nevertheless, there are few studies which prospect an impact of sex education programs on STI rates and teen pregnancies [12].

\section{CONCLUSIONS}

1. Efficient sex education classes increase young people's awareness pf STI, so it is considered as one of the numerous prophylactic methods.

2. Honest classes based on up-to-date medical knowledge contribute to decreased amount of STI and those who might get sick will look for medical advices earlier.

3. Knowledge about natural and artificial methods of contraception decrease the risk of teenage pregnancies.

4. Reliable sex education will help young people to go through that hard teenage time.

\section{REFERENCES}

1. Wellings K, Parker R, Britton A. A reference guide to policies and practicies: Sex education in Europe. IPPF European Network; 2006. [http:// www.laicite-laligue.org/images/PDF/IPPF_sexuality_education.pdf]

2. Federacja na Rzecz Kobiet i Planowania Rodziny. Edukacja seksualna czy Wychowanie do życia w rodzinie? Przepisy prawne i podstawa programowa. [http://www.federa.org.pl/publikacje/edukacja_seksualna factsheet_2013.pdf]

3. Frankowicz-Gasiul B, Michalik A, Czerwińska A, et al. Ciaża młodocianych - problem medyczny i społeczny. Studia ed. 2008;11:57-63.

4. Padała O, Sadowska M, Wdowiak A, et al. Młodociane macierzyństwo jako problem medyczny i społeczny. Eur J Med Tech. 2014;2(3).

5. Gąsiorowski J, Łapiński Ł, Cichewicz A. Choroby przenoszone droga płciową. Med Prakt. [http://dermatologia.mp.pl/choroby/wenerologia/ show.html?id=80452]

6. Federal Centre for Health Education (BZgA), World Health Organization Regional Office for Europe, WHO Regional Office for Europe and BZgA Standards for Sex education in Europe Standards for Sex education in Europe; 2010. p. 10-4.

7. Planned Parenthood Federation of America Inc. Implementing Sex Education. [https://www.plannedparenthood.org/educators/implementing-sexeducation\#sthash.QhFqwtTp.dpuf]

8. Campogni C. A psychological approach to sex education: Is abstinence the answer? [http://www.examiner.com/article/a-psychological-approach-tosex-education-is-abstinence-the-answer]
9. Future of Sex Education Initiative. National Sex education Standards: Core Content and Skills, K-12. A special publication of the Journal of School Health. [http://www.advocatesforyouth.org/publications/publications-az/1947-future-of-sex-education-national-sexuality-education-standards]

10. Stein R. Abstinence-only programs might work, study says. Washington: The Washington Post; 2010. [http://www.washingtonpost.com/wp-dyn/ content/article/2010/02/01/AR2010020102628.html]

11. Sexuality Information and Education Council of the United States. What the Research Says. Comprehensive Sex Education. [http://www.siecus. org/index.cfm? fuseaction=Page. ViewPage\&PageID=1193]

12. Kohler PK, Manhart LE, Lafferty WE. Abstinence-Only and Comprehensive Sex Education and the Initiation of Sexual Activity and Teen Pregnancy. J Adolesc Health. 2008;42(4):344-51. DOI: http://dx.doi.org/10.1016/j. jadohealth.2007.08.026

13. National Center for HIV/AIDS, Viral Hepatitis, STD, and TB Prevention. Effective HIV and STD Prevention Programs for Youth: A Summary of Scientific Evidence. [http://www.cdc.gov/healthyyouth/sexualbehaviors/ pdf/effective_hiv.pdf]

14. American Psychological Association. Based on the Research, Comprehensive Sex Education Is More Effective at Stopping the Spread of HIV Infection, Says APA Committee. [http://www.apa.org/news/press/releases/2005/02/sex-education.aspx]

15. Wilczak M, Więznowska-Mączyńska K, Kątniak M, Opala T. Antykoncepcja hormonalna wśród studentek Akademii Medycznej w Poznaniu. Prz Ginekol Położ. 2006;6(3):143-8.

16. Instytut Badań Edukacyjnych. Opinie i oczekiwania młodych dorosłych (18 latków) oraz rodziców dzieci w wieku 6-17 lat wobec edukacji seksualnej dotyczącej rozwoju psychoseksualnego i seksualności. [https://men.gov.pl/wp-content/uploads/2015/07/ekd prezentacja men_20150617_1310.pdf]

17. Wejbert-Wąsiewicz E. Aborcja - między ideologią a doświadczeniem indywidualnym. Monografia zjawiska. Łódź: Wydawnictwo UŁ; 2010. p. $110-2$.

18. Józefowska A, Kołacka M. Raport Grupy Edukatorów Seksualnych Ponton: Jak naprawdę wygląda edukacja seksualna w Polsce? [http://ponton. org.pl/sites/ponton/files/ralport jaka edukacja seksualna grupa ponton_2009.pdf]

19. Adolescence Committee on Psychosocial Aspects of Child and Family Health and Committee on Adolescence. Sexuality education for Children and Adolescents. Pediatrics. 2001;108;498-502.

20. Kirby DB, Laris BA, Rolleri LA. Sex and HIV Education Programs: Their Impact on Sexual Behaviors of Young People Throughout the World. J Adol Health. 2007;40:206-17.

21. United Nations Educational, Scientific and Cultural Organization. Sexuality education. [http://www.unesco.org/new/en/hiv-and-aids/our-prioritiesin-hiv/sexuality-education/]

22. Santelli JS. Medical Accuracy in Sex education: Ideology and the Scientific Process. Am J Public Health. 2008;98(10):1786-92.

23. United Nations Population Fund. The Evaluation of Comprehensive Sexuality education Programmes: A Focus on the Gender and Empowermen Outcomes. [http://www.unfpa.org/sites/default/files/pub-pdf/UNFPAEvaluationWEB4.pdf]

24. Monbiot G. Joy of sex education. The Guardian News and Media Limited 2011. [http://www.theguardian.com/education/2004/may/11/schools.uk2]

Corresponding author

Małgorzata Drwal

Students' Circle of Medical Simulation

Department of Didactics and Medical Simulation, Medical University of Lublin

Chodźki 19 Str., 20-093 Lublin, Poland

E-mail: gosiadrwal@gmail.com

tel: +48 696446059 